\title{
Renewable energy on animal farms: support system and practical application
}

\author{
Nándor Csatári \\ University of Debrecen Faculty of Agricultural and Food Sciences and Environmental Management, \\ Institute of Land Utilisation, Technology and Regional Development, Debrecen \\ csatarin@agr.unideb.hu
}

\section{SUMMARY}

\begin{abstract}
Renewable energy applications were examined in animal farms. The investment support system for animal farms - which has renewable elements - has been summarized through analyzing the legislation and future prospects. The most important in this topic is the Animal Farm Modernization Support, which had several application periods during the 2007-2013 CAP budgets. For analyzing practical application of renewable energies interviews and farm visits have done in Hajdu-Bihar County. The questions covered the general attributes of the farms and the details of the (existing or planned) renewable energy application. In terms of economic analysis saving, the investment return time and the employment effect were examined. The results show wide variety of applied renewable energy application. The investment supports plays great role in renewable energy projects by lowering the return time; and through additional points in application assessing, which is an incentive for farmers to include renewable energy element in their modernization projects.
\end{abstract}

Keywords: renewable energy, animal husbandry, investments, biogas, biomass

\section{ÖSSZEFOGLALÁS}

Az állattartó telepeken történő megújuló energia használat került vizsgálatra jelent tanulmányban. Az állattenyésztö telepek számára elérhetö beruházási támogatások keretében megújuló energia fejlesztések is támogathatók. A legfontosabb e téren az EMVA által finanszírozott Állattartó Telepek Korszerüsitése (ÁTK) támogatás, melynek több igénylési időszaka is volt a 2007-2013 KAP költségvetési időszakban, némileg változó feltételekkel. A megújuló energia használatának felmérésére telepi interjúk készültek több Hajdú-Bihar megyei állattartó telepen. A kérdések az üzem általános jellemzöit, valamint a (meglévö, vagy tervezett) megújuló energia alkalmazás adataira tértek ki. A felmérés során megújulós energia számos formáját sikerült felvételezni a megkérdezett üzemekben. A válaszok alapján a beruházási támogatások nagy szerepet játszanak, a fejlesztések létrejöttében, mivel csökkentik a megtérülési idöt. Továbbá az ÁTK pályázatok pontozási rendszere is ösztönzést jelent, hogy többletponttal járó megújuló energia fejlesztést tartalmazzon a gazdálkodók pályázata.

Kulcsszavak: megújuló energia, állattenyésztés, beruházás, biogáz, biomassza

\section{INTRODUCTION}

The recent measures in the European Union promote the usage of renewable energies and enhancing the energy efficiency. In the 29/2009 EC directive the European community defined targets in this topic for 2020. According to this document energy efficiency shall be $20 \%$ higher, greenhouse gas (GHG) emission has to be $20 \%$ lower and the share of renewable energy has to be $20 \%$ in energy consumption. Regarding renewable energy share, to reach the community target, each member state has its own target value according to their opportunities (EC, 2009). Hungary takes upon to reach $13 \%$ renewable energy share in this document which increased to $14.65 \%$ in the national renewable energy action plan in 2011 (Hungary, 2010). According to the latest EUROSTAT figures the share of renewable energy was $13.0 \%$ of the EU 28 average, and the Hungarian share was 9.1\% in 2011 (Eurostat, 2013). There is another trend related to the topic: the introduction of cross compliance regulations in agriculture. As a part of this measure the nitrate directive sets instructions on manure usage and handling, biogas production can offer a solution for this.

On a business level in agriculture other factors influence the usage of renewable energies. The most important among these is cost saving. Basically two causes can lead to cost saving: firstly the reduction on energy expenditures itself, secondly through other benefits related to renewable energy usage. For instance more effective manure handling, less straw demand.

In this area the investments usually need high amount of capital and its return time usually exceeds five years. The green electricity feed-in the prices per $\mathrm{kWh}$ in Germany is significantly higher than in Hungary. This difference is the reason why the biogas and solar energy are much more frequent in Germany compare to Hungary. Since the selling prices are not highly subsidized the credit interests are high in Hungary the investment return time is higher therefore less renewable energy application can be seen in our country. Almost only option to lower the return time of renewable energy application is to get support for the project. In the animal farming sector the main possibility is the Animal Farm Modernization Support (Hungarian acronym is ÁTK) in the 2007-2013 CAP budget period.

Animal farms have opportunities in using renewable energy in several ways. On the one hand there are sectors, where the energy demand is continuously high in electricity (e.g. forage grinders, mixers, milk coolers, air ventilation systems) or in heating (e.g. stables for poultry or piglets) On the other hand in extensive farming the renewable technologies can be used as off-gird solutions, because the other alternative to get an electric power connection could be more expensive. Beside the energy demand in agricultural sector there are several products and side products suitable for energy production. For example different kinds of organic manures and 
corn silage could be raw materials for biogas production; plant residues like cereal straw and corn stalk bales could be combusted in boilers. Furthermore solar cells or solar collectors can be mounted on the big roof surfaces of animal farm buildings.

\section{MATERIALS AND METHODS}

The examinations in this article have two directions. On the one hand the support possibilities especially ÁTK will be analyzed through the concerning legislation and the future possibilities via the available rural strategies.

The second field of the examination is the interviews made with animal farm managers in Hajdú-Bihar County between May and November 2013. The data were collected through oral interviews and farm visits. The data collection topics consist of the farm identification data, the technical and the socio-economic attributes of the renewable energy application and the future development plans. In this article the names of the farms are not indicated, they are only referred with a number (Farm1, Farm2 etc.). The recent examination can be considered as trial interviews before a wider range of farm interviews. Therefore I asked farms dealing with different animals, have different renewable energy application and these projects are in different status; in order to develop the questions for a later use.

\section{RESULTS}

\section{Renewable energy support possibilities for animal} farms

\section{Investment support - ÁTK}

The most important investment support program for animal farms is the Animal Farm Modernization Support (the ÁTK is long form of the acronym Állattartó Telepek Korszerúsítése). This program is founded by European Agriculture Fund for Rural Development (EAFRD). In its Hungarian support fund the AEFDR have four axes. The ÁTK support is one of the measures in the First Axis, which titled as Competitiveness of Agriculture and Forestry. The goal of this support program is - as its name indicates - to help technological, machinery and infrastructural investments in animal husbandry sector. Among the numerous supportable items some is related to renewable energy production. Since ÁTK is an investment like support it is post financed, which means support is transferred only after realization and financial fulfilment.

The support intensity is normally $40 \%$, which can be increased by $10 \%$ if the farm area is NATURA 2000 or Naturally Least Favored Area (Hungarian acronym: $\mathrm{KAT}$ ), and/or $+10 \%$ if the applicant is a young farmer (natural person under 40 years).

The support had four application periods in the 2007-2013 CAP budget which are the followings: - ÁTK I. 23 ${ }^{\text {rd }}$ April 2007 - 23 $3^{\text {rd }}$ Maj 2007,

- ÁTK II. $13^{\text {rd }}$ August $2007-17^{\text {th }}$ September 2007,

- ÁTK III. $16^{\text {th }}$ November $2009-15^{\text {th }}$ December 2009,

- ÁTK IV. $1^{\text {st }}$ August 2012 - $31^{\text {st }}$ August 2012.

The basic regulation for the first three application periods was the 27/2007. (IV. 17.) FVM decree (Department of Agriculture and Rural Development)
(FVM, 2007). The basic regulation for the last application period (ÁTK IV.) is the 61/2012. (VI. 29.) VM decree (Department of Rural Development) (VM, 2012a). The final deadline for the winners in ÁTK IV. Completing their projects is 31 st December 2014, and the financial settlement has to be finished by 31 st January 2015 . The last date is also the deadline for paying form EASDF.

Exceptionally in the first application period (ÁTK I.) the intensity was $75 \%$ for manure handling, including biogas plants.

These renewable energy possibilities in ÁTK were collected to three points:

1. manure handling with anaerobic fermentation;

2. boilers using renewable energy, solar collectors with connected heating system;

3. water supply system powered by solar cell or wind energy.

The first option "Manure handling with anaerobic fermentation" means biogas plants. It was available in ÁTK I. I. III. To ensure the adequate farm size for biogas plants, the decree contained requirement that the applicant must have at least 200 livestock unit from cattle, and/or pig, and/or poultry during the compulsory five year maintenance period. The intensity was $75 \%$ in ÁTK I., because it is a part of manure handling measures. Livestock units are defined in the Appendix 5. of 50/2008 FVM decree for each species, the mentioned ones have the following livestock unit:

- bull, cow, or other cattles above 2 years - 1.0;

- cattle between 6 months and 2 years -0.6 ;

- cattle below 6 months -0.4 ;

- sow above $50 \mathrm{~kg}-0.5$;

- other pig 0.3 ;

- hen for egg production - 0.014;

- other poultry - 0.03 (FVM, 2008).

The $2^{\text {nd }}$ and the $3^{\text {rd }}$ options were part of infrastructure measures, which means limitation in application budget share. All the infrastructure expenditures can't exceed 30 percent of the overall budget in an application.

In order to select the winners the submitted applications are assessed according to the given assessing charts in the decrees. Additional points could be acquired if the application contained renewable energy. In the first three application periods 2 points from total 110; and in ÁTK IV. 10 points from total 133.

ÁTK 5.

In December 2013 a new support program opened for animal farm (and food industry) technology modernization. This support is often called as ATK V; however there are major differences comparing the other ÁTK programs. The program supports only stable and mobile machinery and technology, without buildings, because projects including building cannot be finished until the EARDF final deadline, which is $31^{\text {st }}$ December 2014. Unlike the other ÁTK programs, the submitted projects are not evaluated by point system. If a project meets the minimum requirements, the submission time is essential. This kind of evaluating system is faster due to the EARDF final deadline.

The application period is $16^{\text {th }}$ December 2013 and $31^{\text {st }}$ January2014, however to the application is closed by $20^{\text {th }}$ December 2013 due to the high number of submitted application. The intensity is between $40 \%$ and $60 \%$ for 
built-in technologies, depending on the applicant. The total support budget is be 35 billion HUF (VM, 2013).

The IH announcement contains the official MVH Machine Catalog (MVH, 2013) categories In ÁTK 5 the following renewable machines or equipments are supportable (IH, 2013):

- 6213 Biomass heat production equipment and its accessories;

- 6217 Machines and equipments of biogas production and utilization;

- 6219 Machines and equipments of other bioenergy production and utilization;

- 6221 Machines and equipments of solar energy production and utilization;

- 6222 Machines and equipments of wind energy production and utilization;

- 6223 Machines and equipments of water energy production and utilization;

- 6224 Machines and equipments of geothermal energy production and utilization.

Other supports, future prospects

National Diversification Program (NDP) was opened in November 2009. The support was available for farmers in any agricultural sectors in settlements affected with the closing of sugar-beet factories. The aim was to help the diversification of the production for farmers, therefore the supportable measures have very wide range. The intensity of the support was $60 \%$.
Among the small-scale infrastructure development measures, renewable energy utilization was supported for hot water production, heating, electricity generating (FVM, 2009).

Regarding future prospects the importance of animal production and environment protection is stated in Darányi Ignác National Rural Strategy, therefore in the next EARDF budget period there will be also supports for renewable energy projects in animal farms (VM, 2012b).

\section{Farm interviews}

The questions of the interview can be divided to the following topics:

- identification data (branch, livestock amount);

- technical attributes of renewable energy investment (type, capacity, saved energy, resources used);

- socio-economic attributes of renewable energy investment (finance, support, total cost, savings, return period, additional employment, status of project, estimated time of finish);

- future development plans.

The oral interviews and farm visits were covered eight animal farms in Hajdú-Bihar county. Regarding the branches of the businesses there were six was dairy cattle farms, one beef cattle farm and one pork farm.

The summary of applied renewable energy solutions on interviewed farms are shown in Table 1.

Table 1

Summary of the technological attributes of renewable energy usage on interviewed farms

\begin{tabular}{|c|c|c|c|c|c|c|c|c|}
\hline & Farm1 & Farm2 & Farm3 & Farm4 & Farm5 & Farm6 & Farm7 & Farm8 \\
\hline $\begin{array}{l}\text { Animal } \\
\text { branch }\end{array}$ & $\begin{array}{l}\text { Dairy farm, } \\
\text { pork farm }\end{array}$ & $\begin{array}{l}\text { Dairy cattle } \\
\text { farm }\end{array}$ & $\begin{array}{l}\text { Dairy cattle } \\
\text { farm }\end{array}$ & Pork farm & $\begin{array}{l}\text { Beef cattle } \\
\text { farm }\end{array}$ & $\begin{array}{l}\text { Dairy cattle } \\
\text { farm }\end{array}$ & $\begin{array}{l}\text { Dairy cattle } \\
\text { farm }\end{array}$ & $\begin{array}{l}\text { Dairy cattle } \\
\text { farm }\end{array}$ \\
\hline Animals & $\begin{array}{l}1800 \text { dairy } \\
\text { cows, } \\
600 \text { sows }\end{array}$ & $\begin{array}{c}700 \\
\text { dairy cows }\end{array}$ & $\begin{array}{c}580 \\
\text { dairy cows }\end{array}$ & sows & $\begin{array}{c}100 \\
\text { beef cows }\end{array}$ & $\begin{array}{c}620 \\
\text { dairy cows }\end{array}$ & $\begin{array}{c}400 \\
\text { dairy cows }\end{array}$ & $\begin{array}{c}700 \\
\text { dairy cows }\end{array}$ \\
\hline $\begin{array}{l}\text { Renewable } \\
\text { energy type }\end{array}$ & $\begin{array}{c}\text { Biogas } \\
\text { plant }\end{array}$ & $\begin{array}{c}\text { Solar } \\
\text { collector }\end{array}$ & - & $\begin{array}{l}\text { Big bale } \\
\text { boiler }\end{array}$ & $\begin{array}{l}\text { Solar } \\
\text { cells }\end{array}$ & $\begin{array}{c}\text { Biomass } \\
\text { boiler }\end{array}$ & $\begin{array}{c}\text { Solar } \\
\text { collector }\end{array}$ & $\begin{array}{c}\text { Solar collector } \\
+ \text { small bale boiler } \\
\end{array}$ \\
\hline $\begin{array}{l}\text { Renewable } \\
\text { energy } \\
\text { capacity, } \\
\text { attributes }\end{array}$ & $\begin{array}{l}\text { Fermenter } \\
2400 \mathrm{~m}^{3}, \\
\text { gas engine } \\
625 \mathrm{~kW}\end{array}$ & $\begin{array}{c}11 \text { panels, } \\
22 \mathrm{~m}^{2} \text { surface }\end{array}$ & - & $\begin{array}{c}600 \mathrm{~kW}, \\
\text { puffer tank } \\
50 \mathrm{~m}^{3}\end{array}$ & $\begin{array}{c}48 \text { panels, } \\
\text { surface } 96 \mathrm{~m}^{2}, \\
12 \mathrm{kWp}, \\
13.2 \mathrm{kWh} / \mathrm{yr}\end{array}$ & & $\begin{array}{c}2 \text { panels, } \\
4 \mathrm{~m}^{2} \text { surface }\end{array}$ & $\begin{array}{c}14 \text { panels, } \\
28 \mathrm{~m}^{2} \text { surface; } \\
3 \text { boilers } \\
220 \mathrm{~kW} \text { total } \\
\text { capacity }\end{array}$ \\
\hline $\begin{array}{l}\text { Saved } \\
\text { energy }\end{array}$ & Electricity & $\begin{array}{c}\text { Heating water } \\
\text { in milking } \\
\text { house }\end{array}$ & - & $\begin{array}{l}\text { Heating } \\
\text { stables, } \\
\text { instead of } \\
\text { natural gas }\end{array}$ & Electricity & $\begin{array}{l}\text { Heats general } \\
\text { building }\end{array}$ & $\begin{array}{l}\text { Heating water } \\
\text { in milking } \\
\text { house, } \\
\text { instead of } \\
\text { natural gas }\end{array}$ & $\begin{array}{c}\text { Hot water in } \\
\text { milking house, } \\
\text { instead of PB; } \\
\text { it heats general } \\
\text { buildings }\end{array}$ \\
\hline $\begin{array}{l}\text { Status of } \\
\text { realization }\end{array}$ & In use & In use & - & In use & $\begin{array}{l}\text { Permits ready, } \\
\text { in progress }\end{array}$ & In use & In use & In use \\
\hline $\begin{array}{l}\text { Start of } \\
\text { operation }\end{array}$ & 2011 & 2003 & - & 2011 & 2014 & 1990 & 2013 & 2013 \\
\hline
\end{tabular}

Six of the farms use some kind of renewable energy solution. The results show wide range of these application, because there is one biogas plant, two biomass boilers the one is for big bales, the other for small ones, there are three solar collectors.
The Farm1 has a biogas plant and uses slurry from both dairy cattle and pig branches. In the dairy farm 1000 cows placed in stables using slurry technology, therefore the manure from the rest of the cows is not used for the biogas plant. The amount of dairy input is 
$120 \mathrm{~m}^{3}$ cattle slurry, and $50 \mathrm{~m}^{3}$ pig slurry and silage corn as a supplement. Beside the produced energy the investment was made to use more cost-efficient slurry handling and save straw in cow stables. Residual heat has not yet utilized.

The Farm2 uses a complete solution to lower the water heating cost in milking house. The water heating system firstly uses the waste heat of milk cooling tanks, then it heats the water through solar collectors. If the previous solutions don't heat water enough there is an electric boiler. This complex heating system only generates hot water, it has no connection with the heating system.

The Farm 3 made calculation and building plans for a biogas plant with $530 \mathrm{~kW}$ gas engine and $1300 \mathrm{~m}^{3}$ fermenter capacity, but the implementation was delayed. The main reason for skipping the project was that the biogas plant also has its demand for silage corn, and the farm does not have additional arable lands for feeding the biogas plant as well.

The Farm 4 built a biomass boiler for big bales in 2011, which has $60 \%$ less operating cost than the previous natural gas boilers.

The Farm5 plans to install solar panels on the stable roof to generate electricity. The planned capacity of the solar panels is close to the annual consumption.

The Farm6 uses old mixed boilers for heating general buildings.

The Farm 7 installed two solar collectors on the roof of the milking house for helping to heat the water and lower the costs.

The Farm 8 invested to two different renewable solutions in 2013. Firstly the hot water production in the milking house is provided by solar collectors, and a new propane-butane gas boiler was purchased for supplementary heating. Secondly the heating system in general buildings replaced from PB gas boilers to small bale biomass boilers fed by rape straw and wheat straw.

Summary of socio-economic attributes of renewable energy solutions on interviewed farms is shown in Table 2.
The expected investment return time includes the support (if any), and has lower value than without it. In case of the Farm2 the farm manager couldn't say value for return time, because the combined water heating system with waste heat was part of the building's technology from the beginning.

Only two farms (the Farm1, the Farm5) sell energy in the electricity grid: the biogas plant and the solar cell, it is because other renewable solutions are for heat production, not electricity. In case of the solar cells it is only theoretical and means a two way electricity consumption counter, because the expected electricity production is a bit less than the annual consumption. The capacity was designed for this size for a purpose, because saved electricity has higher price than a sold (if there is a surplus). Therefore the additional investment for bigger output than the consumption has significantly higher return time.

All the examined farmers have experiences at least in one of EARDF projects, mostly ÁTK support.

Three farms submitted application for ÁTK IV in 2012. All of them have some renewable elements in their application for additional points in assessment, and all three farms won. In case of the Farm7 that was the main goal by installing only 2 panels.

The Farm 1 employs 6 additional workers for its biogas plant. In case of biomass combustion some additional workers hours were recorded, but the values didn't reach a full worker, therefore these numbers are mainly theoretical.

Six from the eight of the farms have further development plans in renewable energy. The Farm1 plans to increase its biogas plant if all sables will have a slurry technology, and to use biogas (after cleaning) for their gas boilers. They plan also to use the waste heat of the gas engine for some purpose. The Farm2 has an application for biogas plant, but its realization is still in question. The Farm3 plans (beside the biogas plant) to lower the heating and hot water cost of the main building by installing solar collectors. The Farm 4 is about to build more stables

Summary of the socio-economic attributes of renewable energy usage on interviewed farms

\begin{tabular}{|c|c|c|c|c|c|c|c|c|}
\hline & Farm1 & Farm2 & Farm3 & Farm4 & Farm5 & Farm6 & Farm7 & Farm8 \\
\hline Support fund & $\begin{array}{c}\text { ÁTK I. } \\
75 \%\end{array}$ & - & - & $\begin{array}{c}\text { ÁTK III. } \\
40 \%\end{array}$ & $\begin{array}{c}\text { ÁTK IV. } \\
50 \%\end{array}$ & - & $\begin{array}{c}\text { ÁTK IV. } \\
40 \%\end{array}$ & $\begin{array}{c}\text { ÁTK IV. } \\
40 \%\end{array}$ \\
\hline $\begin{array}{l}\text { Expected } \\
\text { return time } \\
\text { (incl. support) }\end{array}$ & 5 years & $?$ & - & 2-3 years & 6.5 years & - & 3 years & $\begin{array}{c}3 \text { years, } \\
1 \text { year }\end{array}$ \\
\hline Energy selling & Yes & No & - & No & Yes & No & No & No \\
\hline $\begin{array}{l}\text { Additional } \\
\text { employment }\end{array}$ & 6 workers & - & - & 0.5 worker & - & - & - & 0.2 worker \\
\hline $\begin{array}{l}\text { Experience } \\
\text { in EARDF } \\
\text { programs } \\
\end{array}$ & Yes & Yes & Yes & Yes & Yes & Yes & Yes & Yes \\
\hline $\begin{array}{l}\text { Further } \\
\text { renewable plans }\end{array}$ & Yes & Yes & Yes & Yes & Yes & No & No & Yes \\
\hline $\begin{array}{l}\text { Further } \\
\text { renewable plans } \\
\text { in detail }\end{array}$ & $\begin{array}{l}\text { Increase biogas } \\
\text { plant capacity, } \\
\text { biogas for heating } \\
\text { gas boilers }\end{array}$ & $\begin{array}{l}\text { Biogas } \\
\text { plant? }\end{array}$ & $\begin{array}{l}\text { Solar collectors } \\
\text { for office } \\
\text { buildings; } \\
\text { Biogas plant? }\end{array}$ & $\begin{array}{l}\text { More stables, } \\
\text { increase } \\
\text { biomass heating } \\
\text { capacity }\end{array}$ & $\begin{array}{l}\text { Increase solar cells } \\
\text { capacity, biomass } \\
\text { heating for general } \\
\text { buildings }\end{array}$ & - & - & $\begin{array}{c}\text { Solar cells } \\
\text { on stable } \\
\text { roof }\end{array}$ \\
\hline
\end{tabular}


for their pigs, which buildings also will be heated with big bale boilers. The Farm5 plans to heat the social building and the machine workshop with a small bale biomass boiler, and increase solar cell capacity if electricity consumption grows. The Farm6 and the Farm7 don't have any further plans regarding renewable energies. The Farm8 is planning to mount solar cells on the roof of the newly built stable in $500 \mathrm{kWp}$ magnitude.

\section{CONCLUSION}

The examined farms provided useful information regarding the practical application in renewable energy topic.

- The renewable energy investments have high capital demand; their return period usually exceeds five years, even with support, except for replacing natural gas or PB gas boilers. Projects mostly start when support fund, can be added.

- All the examined farmers have experiences at least in one of EARDF projects, mostly ÁTK support.

- ÁTK support application gave opportunities for renewable energy projects in animal farms. Furthermore as a part of a complex farm modernization project, though additional points, renewable energy solutions gave higher chance of winning the application.

- Only biogas and biomass combustion resulted higher employment in animal farms

- All the farms are aware of the renewable energy options, and most of them have further plans in this topic.

- It is advised to the businesses to seek the best suitable technologies in energy saving by consulting external experts and benchmarking, and to adopt the good practices from other businesses.

- The main motive for farmers using renewable energy is cost saving (and ensuring the winning of an application). For making the right decision it is essential to make exact return calculations, and (if available) to seek additional finance sources from supports.

As a result of this present survey the questionnaire will be modified for the later research, because the technical attributes cannot be properly compared if more farms are interviewed. The questions will focus mainly to the knowledge and attitude of farmers in the renewable energy topic. Technical attributes will be used for calculations in case of defined sample farms.

\section{REFERENCES}

EC (2009): 2009/28/EC directive of the European Parliament and of the Council of 23 April 2009, on the promotion of the use of energy from renewable sources and amending and subsequently repealing Directives 2001/77/EC and 2003/30/EC; downloaded: $16^{\text {th }}$ January, 2014; http://eur-lex.europa.eu/LexUriServ/LexUriServ. do?uri=OJ:L:2009:140:0063:0087:en:PDF

Eurostat (2013): Share of energy from renewable sources. http:// appsso.eurostat.ec.europa.eu/nui/show.do?dataset=nrg_ind_335 a\&lang $=$ en $16^{\text {th }}$ January 2014

FVM (2007): 27/2007. (IV.17.) FVM rendelet, az Európai Mezőgazdasági Vidékfejlesztési Alapból az állattartó telepek korszerüsítéséhez nyújtandó támogatások részletes feltételeiről. http:// www.njt.hu/cgi_bin/njt_doc.cgi?docid $=109602.22623716^{\text {th }}$ January 2014

FVM (2008): 50/2008. (IV. 24.) FVM rendelet az egységes területalapú támogatások és egyes vidékfejlesztési támogatások igényléséhez teljesítendő „Helyes Mezőgazdasági és Környezeti Állapot” fenntartásához szükséges feltételrendszer, valamint az állatok állategységre való átváltási arányának meghatározásáról. http://www.njt.hu/cgi_bin/njt_doc.cgi?docid=117887.241323 $16^{\text {th }}$ January 2014

FVM (2009): 148/2009. (XI. 6.) FVM rendelet a Nemzeti Diverzifikációs Program keretében a mikrovállalkozások létrehozására és fejlesztésére nyújtandó támogatások részletes feltételeiről. http://njt.hu/cgi_bin/njt_doc.cgi?docid=126147.181807 $16^{\text {th }}$ January 2014
IH (2013): Irányító Hatóság 303/2013. (XII. 16.) közleménye az Európai Mezőgazdasági Vidékfejlesztési Alapból egyes jogcímek esetében technológiai berendezések korszerüsítés céljából történő beszerzéséhez nyújtandó támogatások részletes feltételeiről szóló 116/2013 (XII.12.) VM rendeletről - appendices. http:// umvp.kormany.hu/download/e/02/90000/IHk_2013_303_(XII_ 16)_IHkozlemeny_mell\%C3\%A9klet.zip $16^{\text {th }}$ January 2014

MVH (2013): Machine Catalog for EAGGF support programs. http://www.mvh.gov.hu/portal/MVHPortal/default/mainmenu/alkalmazasok/viewer/1000001 $16^{\text {th }}$ January 2014

Renewable Energy Utilization Action Plan of Hungary (2010): http://www.kormany.hu/download/2/88/20000/NCsT_20110106 _\% \%C3\%A9gleges_201103.pdf $16^{\text {th }}$ January 2014

VM (2012a): 61/2012. (VI. 29.) VM rendelet, az Európai Mezőgazdasági Vidékfejlesztési Alapból az állattartó telepek korszerűsítéséhez 2012. évtöl nyújtandó támogatások részletes feltételeiről. http://www.njt.hu/cgi_bin/njt_doc.cgi?docid=151063. $24063316^{\text {th }}$ January 2014

VM (2012b): Darányi Ignác National Rural Strategy 2012-2020. http://www.kormany.hu/download/6/30/70000/DIT_kiadvany_ 210x148mm_LEADv\%C3\%A9gs\%C5\%91-v\%C3\%A9gs\% C5\%91.pdf $16^{\text {th }}$ January 2014

VM (2013): 116/2013. (XII. 12.) VM rendelet, az Európai Mezőgazdasági Vidékfejlesztési Alapból egyes jogcímek esetében technológiai berendezések korszerüsítés céljából történő beszerzéséhez nyújtandó támogatások részletes feltételeiről. http://njt.hu/ cgi_bin/njt_doc.cgi?docid=165399.253368 $16^{\text {th }}$ January 2014 
